Original Article

\title{
In vitro cytotoxicity of curcuminoids against head and neck cancer HNO97 cell line
}

\author{
Citotoxicidade in vitro de curcuminoides contra a linhagem de células HNO97 de \\ câncer de cabeça e pescoço
}

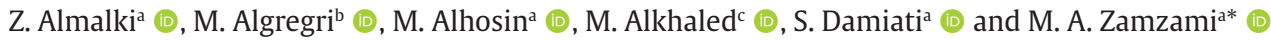 \\ ${ }^{a}$ King Abdulaziz University, Faculty of Science, Department of Biochemistry, Jeddah, Saudi Arabia \\ 'King Abdulaziz University, King Fahad Medical Research Canter, Jeddah, Saudi Arabia \\ cUniversity of Jeddah, Faculty of Science, Department of Biological Sciences, Jeddah, Saudi Arabia
}

\begin{abstract}
Oral squamous cell carcinoma (OSCC) is a malignant tumour of Head and Neck Cancer (HNC). The recent therapeutic approaches used to treat cancer have adverse side effects. The natural agents exhibiting anticancer activities are generally considered to have a robust therapeutic potential. Curcuminoids, one of the major active compounds of the turmeric herb, are used as a therapeutic agent for several diseases including cancer. In this study, the cytotoxicity of curcuminoids was investigated against OSCC cell line HNO97. Our data showed that curcuminoids significantly inhibits the proliferation of HNO97 in a time and dose-dependent manner (IC50=35 $\mu \mathrm{M})$. Cell cycle analysis demonstrated that curcuminoids increased the percentage of G2/M phase cell populations in the treated groups. Treating HNO97 cells with curcuminoids led to cell shrinking and increased detached cells, which are the typical appearance of apoptotic cells. Moreover, flow cytometry analysis revealed that curcuminoids significantly induced apoptosis in a time-dependent manner. Furthermore, as a response to curcuminoids treatment, comet tails were formed in cell nuclei due to the induction of DNA damage. Curcuminoids treatment reduced the colony formation capacity of HNO97 cells and induced morphological changes. Overall, these findings demonstrate that curcuminoids can in vitro inhibit HNC proliferation and metastasis and induce apoptosis.
\end{abstract}

Keywords: apoptosis, cell cycle, DNA damage, curcuminoids, proliferation.

\begin{abstract}
Resumo
O carcinoma de células escamosas oral (OSCC) é um tumor maligno do câncer de cabeça e pescoço (HNC). As recentes abordagens terapêuticas usadas para tratar o câncer têm efeitos colaterais adversos. Os agentes naturais que exibem atividades anticâncer são geralmente considerados como tendo um potencial terapêutico robusto. Curcuminoides, um dos principais compostos ativos da erva cúrcuma, são usados como agente terapêutico para várias doenças, incluindo câncer. Neste estudo, a citotoxicidade dos curcuminoides foi investigada contra a linha de células OSCC HNO97. Nossos dados mostraram que os curcuminoides inibem significativamente a proliferação de HNO97 de forma dependente do tempo e da dose $($ IC50 $=35 \mu \mathrm{M})$. A análise do ciclo celular demonstrou que os curcuminoides aumentaram a porcentagem de populações de células da fase G2 / M nos grupos tratados. O tratamento das células HNO97 com curcuminoides levou ao encolhimento celular e ao aumento das células destacadas, que são a aparência típica das células apoptóticas. Além disso, a análise de citometria de fluxo revelou que os curcuminoides induziram significativamente a apoptose de uma maneira dependente do tempo. Além disso, em resposta ao tratamento com curcuminoides, caudas de cometa foram formadas nos núcleos das células devido à indução de danos ao DNA. 0 tratamento com curcuminoides reduziu a capacidade de formação de colônias das células HNO97 e induziu alterações morfológicas. No geral, esses achados demonstram que os curcuminoides podem inibir in vitro a proliferação e metástase de HNC e induzir apoptose.
\end{abstract}

Palavras-chave: apoptose, ciclo celular, dano ao DNA, curcuminoides, proliferação.

\section{List of abbreviations}

Bisdemethoxycurcumin (BDMC), Desmethoxycurcumin (DMC), Dulbecco's Modified Eagle Medium (DMEM), Fetal bovine serum (FBS), Half lethal dose (LD50), Half-maximal inhibitory concentration (IC50), Head and Neck Cancer
(HNC), Human oral squamous cell carcinoma (HNO97, Human papillomavirus (HPV), Maximum tolerated dose (MTD), Oral squamous cell carcinoma (OSCC), Phosphate buffer saline (PBS), Water-soluble tetrazolium salt (WST-1).

*e-mail: mzamzami@kau.edu.sa

Received: February 12, 2021 - Accepted: March 17, 2021 


\section{Introduction}

Head and neck cancer (HNC) is generally defined as a span of malignant neoplasms that originate from the soft tissues include the oral and nasal cavities, sinuses, lips, salivary glands, throat, and larynx (Joshi et al., 2014). HNC is mostly caused by tobacco and alcohol consumption, and recently, the human papillomavirus (HPV) has been found as another important cause of HNC (van Harten et al., 2020). According to the GLOBOCAN 2018 statistics, the estimated number of new HNC diagnosed and deaths were about 705,781 and 358,144 , respectively. Current therapeutic regimens for HNC based on surgery, radiotherapy, and chemotherapy, often in combination, resulting in negative side effects such as malformation and failure of some organs (Seront et al., 2019). Moreover, the development of drug resistance by cancer cells is another challenge associated with currently available chemotherapeutic approaches (Ramezani et al., 2019). Therefore, there is an urgent need to find new selective drugs to minimize the adverse effects of current cancer therapeutic approaches and to improve clinical outcomes.

The natural agents isolated from medicinal herbs have been used for the treatment of numerous diseases from ancient times. Several natural compounds have been identified as effective agents in the prevention and treatment of HNC (Crooker et al., 2018). Among the pharmacological active natural compounds, curcuminoids have attracted the interest of medical scientists. Curcuminoids are a spice with a yellow colour extracted from the roots of the Curcuma longa herb (Turmeric), which belongs to the ginger family (Shakeri et al., 2019). Curcuminoids consist of diferuloylmethane (curcumin), which is the most abundant (74.9\%), desmethoxycurcumin (DMC) (20.1\%), and Bisdemethoxycurcumin (BDMC) (4.9\%) (Almosa et al., 2020). Besides, Curcuminoids are widely used as a colouring and flavouring agent as well as a food preservative agent due to its antioxidant and antibacterial properties (Anand et al., 2008). Further, curcumin has been consumed as a dietary supplement since it is considered safe and does not have side effects (Anand et al., 2008). However, at a daily dose of more than $8 \mathrm{~g} /$ day, it may cause gastrointestinal disturbance and abdominal pain (Mishra and Palanivelu, 2008). The maximum tolerated dose (MTD) and the half lethal dose (LD50) of curcumin were found to be about $250 \mathrm{mg} / \mathrm{kg}$ and $500 \mathrm{mg} / \mathrm{kg}$, respectively (Govind, 2011). The beneficial effects of curcuminoids are related to their antioxidant, anti-inflammatory, and anticancer properties (Xu et al., 2018). In addition, curcuminoids are able to modulate cancer progression by targeting multiple signaling pathways such as cell proliferation, apoptosis, angiogenesis, invasion and metastasis (Wang et al., 2019). In vitro studies indicated that curcumin was able to treat different types of cancer, such breast cancer (Song et al., 2019), prostate cancer (Zhu et al., 2019), and ovarian cancer (Liu et al., 2019). On the other hand, recent reports have demonstrated that DMC (Lin et al., 2018) and BDMC (Ramezani et al., 2018) have the similar biological potential of curcumin. Recently, we have reported that a mixture of three curcuminoids is more potent than individual curcuminoid, thereby suggesting the possible synergistic effect (Almosa et al., 2020).

Based on the previous findings that three curcuminoids compounds- curcumin, DMC and BDMC, exhibit individually a strong anti-proliferative activity in multiple cancer types in different potencies, the present study was undertaken to investigate the combined effect of the three main curcuminoids, employed as one sample against HNO97 cell line, which is the most frequent malignant cancer in the oral cavity.

\section{Materials and Methods}

\subsection{Cell culture}

Human oral squamous cell carcinoma (HNO97 cell line) was obtained from Cell Lines Services (California, USA). HNO97 cells were grown in Dulbecco's Modified Eagle Medium (DMEM) (UFC-Biotech, SA) supplemented with $15 \%(\mathrm{v} / \mathrm{v})$ fetal bovine serum (FBS) (ThermoFisher, USA), penicillin $(100 \mathrm{IU} / \mathrm{mL})$, and streptomycin $(100 \mu \mathrm{g} / \mathrm{mL})$ (UFC-Biotech, SA.). Cells were maintained in a humidified incubator containing $5 \% \mathrm{CO}_{2}$ at $37{ }^{\circ} \mathrm{C}$.

\subsection{Preparation of curcuminoids solutions}

Curcuminoids from India Glycols Ltd. was kindly provided by Jamjoom Pharma (Jeddah, Saudi Arabia). Curcuminoids purity was $96.3 \%$. A stock solution of $10 \mathrm{mM}$ of curcuminoids was prepared in Dimethyl sulfoxide (DMSO). Dilutions were prepared in 2\% FBS-DMEM to obtain $5,15,25,35,45,55$ and $65 \mu \mathrm{M}$ of curcuminoids for WST-1 Proliferation assay. For subsequent experiments, $35 \mu \mathrm{M}$ of curcuminoids has been used.

\subsection{WST-1 Proliferation assay}

Water-soluble tetrazolium salt (WST-1) assay (Abcam, UK) was used to examine the cytotoxic effects of curcuminoids against HNO97 cells. HNO97 cells were seeded in 96-multiwell plates at a density of $1 \times 10^{4}$ cells/well in $200 \mu \mathrm{L}$ medium. After $24 \mathrm{~h}$, the culture supernatant was discarded and 2\% FBS-DMEM containing desired curcuminoids concentrations were added and incubated for $6,12,24$, and $48 \mathrm{~h}$. At each different well, $10 \mu \mathrm{M}$ WST-1 regent was added and the culture were incubated for $3 \mathrm{~h}$ at a humidified incubator containing $5 \% \mathrm{CO}_{2}$ at $37^{\circ} \mathrm{C}$. The absorbance was measured at $450 \mathrm{~nm}$ using an ELISA reader.

\subsection{Morphological assay}

Observation of morphological changes of apoptotic cells was performed as described previously (Rahman et al., 2013). Briefly, HNO97 cells were seeded in 12-multi-well plates at a density of $2 \times 10^{5}$ cells/well and grown for $24 \mathrm{~h}$ following with treatment with $35 \mu \mathrm{M}$ of curcuminoids for desired time points ( 24 and $48 \mathrm{~h}$ ). For morphological changes evolution, the HNO97 cells were fixed with 4\% paraformaldehyde (Sigma-Aldrich, USA) and stained with of Giemsa stain following the manufacturer's instructions (Sigma-Aldrich, USA). The cells morphological changes 
were observed and captured using a phase-contrast microscope (20x).

\subsection{Apoptosis assay}

For the detection of apoptosis, cells were grown $1 \times 10^{5}$ cells/well in 6 -well plates. Following $24 \mathrm{~h}$ of incubation at $37^{\circ} \mathrm{C}$, cells were treated with $35 \mu \mathrm{M}$ of curcuminoids for desired time points $(6,12,24$ and $48 \mathrm{~h})$. The percentage of apoptotic cells was determined by flow cytometry using the APC-Annexin assay (BD Biosciences, USA) according to the manufacturer's recommendations. Briefly, cells were harvested, washed with phosphate buffer saline (PBS), and resuspended in $1 \mathrm{x}$ binding buffer (BD Biosciences, USA). Subsequently, the cells were stained with $5 \mu$ l APC-Annexin and incubated for 5 minutes in the dark, then the stained cells immediately analysed using FACS flow cytometry (BD Biosciences, USA).

\subsection{Cell cycle analysis}

Cell cycle distribution was evaluated using Hoechst 33342 (Thermo-Fisher, USA) according to the manufacturer's protocol. HNO97 cells were seeded $1 \times 10^{6}$ cells in $25 \mathrm{~cm}^{2}$ flask) and incubated for $24 \mathrm{~h}$. Cells were then treated with $35 \mu \mathrm{M}$ of curcuminoids for desired time points. After incubation, cells were harvested, washed with PBS, and resuspended in $1 \mathrm{x}$ binding buffer. Subsequently, the cells were fixed with ice-cold 70\% ethanol (Sigma-Aldrich, USA) and stained with Hoechst 33342. After 45 minutes of incubation in the dark, the stained cells were analysed using a FACS flow cytometer.

\subsection{COMET assay for DNA damage detection}

DNA damage detection was performed as previously described (Tice et al., 2000) using a COMET assay kit (Trevigen, USA). HNO97 cells were seeded in 6-well plates at $2 \times 10^{5}$ cells/well and incubated in a humidified incubator. After treatment, the cells were harvested, washed with $1 \mathrm{~mL}$ of Hanks' Balanced Salt Solution (Gibco, USA), and resuspended in $1 \mathrm{ml}$ of ice-cold PBS. The volume of resuspended pellets containing approximately 10,000 cells was mixed with $100 \mu \mathrm{l}$ of $1 \%$ low melting point agarose and loaded on two wells of COMET slides. Next, the gel was allowed to solidify on a cold surface then immersed in cold lysing solution at $4{ }^{\circ} \mathrm{C}$ for $1 \mathrm{~h}$. After the lysis, the slides were placed in a horizontal electrophoresis apparatus that was filled with an alkaline solution for 20 minutes then subjected to electrophoresis for 20 minutes at $0.9 \mathrm{Volt} / \mathrm{cm}$. Slides were transferred to a neutralization buffer (0.4M Tris, $\mathrm{pH} 7.5$ ) and stained with $75 \mu$ Lethidium bromide $(20 \mu \mathrm{g} / \mathrm{mL})$ (Sigma-Aldrich, USA). The slides were covered and analysed at 40x magnification using fluorescent microscopy (100 randomly selected comets from two microscope slides were analysed).

\subsection{Colony formation assay}

The colony formation assay was carried out according to (Crowley et al., 2016). After treatment with $35 \mu \mathrm{M}$ of curcuminoids for $24 \mathrm{~h}$, cells were harvested and re-plated into fresh DMEM and incubated for 14 days to allow control cells to form colonies. Next, treated and untreated colonies were washed with PBS and fixed with $4 \%$ paraformaldehyde for 30 minutes. Subsequently, colonies were washed with PBS and stained with $1 \mathrm{~mL}$ of $0.5 \%$ crystal violet (Sigma-Aldrich, USA) for 20 minutes. The resulting colonies were examined under a phase-contrast microscope and photographed $(4 \mathrm{x})$.

\subsection{Statistical analysis}

The data are presented as the mean values \pm standard error of the mean (SEM) from two or three different replicates for individual assays. The statistical significance was determined by performing a Student t-test using GraphPad PRISM statistical analysis software (GraphPad, USA). The values of ${ }^{*} \mathrm{p}<0.05,{ }^{* *} \mathrm{p}<0.01$ and ${ }^{* * *} \mathrm{p}<0.001$ indicated statistical significance, compared to untreated control cells.

\section{Results}

\subsection{Curcuminoids inhibited the proliferation of HNO97 cells}

To investigate the anti-proliferative effects of curcuminoids against HNO97 cells, cells were treated with increasing concentrations of curcuminoids for $24 \mathrm{~h}$. The cell proliferation rate was then detected through a rapid WST-1 assay (Figure 1). Curcuminoids significantly inhibited
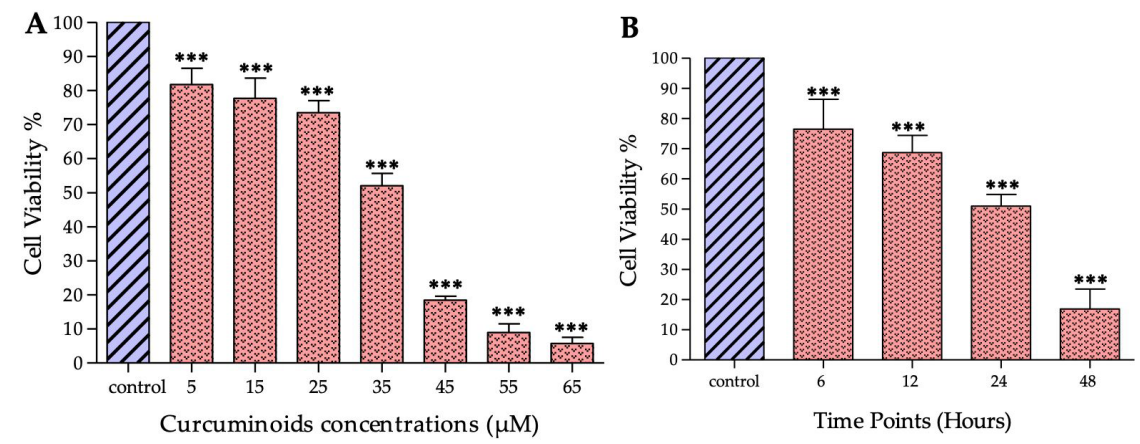

Figure 1. Inhibitory effects of curcuminoids against HNO97 cell proliferation. (A) Dose-dependent effect of curcuminoids for $24 \mathrm{~h}$ detected by WST-1; (B) Time course effect of $35 \mu \mathrm{M}$ of curcuminoids on HNO97 cell viability for different time periods using WST-1. Values are means \pm SEM. ${ }^{* * *} \mathrm{p}<0.001$ considered statistical significance compared to the untreated cells. 
cell proliferation starting from the concentration of $5 \mu \mathrm{M}$ and the inhibition percentage reached approximately $50 \%$ at $35 \mu \mathrm{M}$ suggesting that curcuminoids exert its inhibitory effects on HNO97 with an estimated IC50 value of approximately $35 \mu \mathrm{M}$ (Figure 1A). In the next step, a kinetic analysis of curcuminoids on cell proliferation of HNO97 was carried out using $35 \mu \mathrm{M}$. Figure 1B shows that curcuminoids significantly reduced cell proliferation to about $76 \%, 69 \%, 51 \%$, and $17 \%$ at $6,12,24$, and $48 \mathrm{~h}$, respectively. These data suggest that curcuminoids inhibit HNO97 cell proliferation in a dose- and time-dependent manner.

\subsection{Curcuminoids induced morphological changes of HNO97 cells}

To evaluate the effect of curcuminoids on HNO97 cells morphology, HNO97 cells were treated with curcuminoids at $35 \mu \mathrm{M}$ and examined under a phase-contrast microscope. Figure 2 shows obvious changes in morphological characteristics after 24 and $48 \mathrm{~h}$ of curcuminoids exposure. Curcuminoids treatment led to cell shrinking and increased detached cells compared to untreated cells. As such characteristics are the typical appearance of apoptotic cells, therefore, our observations indicate that curcuminoids induced morphological changes of HNO97 cells.

\subsection{Curcuminoids induced apoptosis of HNO97 cells}

To determine whether curcuminoids-induced proliferation inhibition in HNO97 is related to the induction of the apoptosis process, the percentage of apoptotic cells was analysed using flow cytometry. HNO97 cells were treated with $35 \mu \mathrm{M}$ of curcuminoids for various time points and then stained with APC-Annexin. Figure 3A shows that curcuminoids induced apoptosis of HNO97 cells in a time-dependent manner. Indeed, curcuminoids caused a significant increase in the number of apoptotic cells after $6 \mathrm{~h}$. The percentage of apoptotic cells in the early stage reached approximately 31.9 and $57.3 \%$ after 12 and $24 \mathrm{~h}$, respectively (Figure 3B). These findings suggest that curcuminoids induce apoptosis in HNO97 in a time-dependent mechanism.

\subsection{Effect of curcuminoids on HNO97 cell cycle distribution}

To obtain further evidence confirming the anti-cancer activity of curcuminoids against HNO97 cells, cell cycle distributions were determined using flow cytometry after treatment with $35 \mu \mathrm{M}$ of curcuminoids for 6,12 and 24 and $48 \mathrm{~h}$. Cells were separated into cell cycle phases based on Hoechst 33342 stain incorporation and DNA content (Figure 4 A). Untreated HNO97 cells showed a typical cell cycle pattern with $1.4 \%$ cells at the sub G1 phase, $60 \%$ cells at the G0/G1 phase, $28 \%$ cells at the $S$ phase, and $2.6 \%$ cells at the G2/M phase. Exposure of HNO97 cells to $35 \mu \mathrm{M}$ of curcuminoids for $6 \mathrm{~h}$ led to a significant increase in the percentage of cells at sub G1, a significant decrease in the percentage of cells at the G1/G0 phase as well as a significant increase in the percentage of G2/M phase cell populations (Figure 4B). Indeed, curcuminoids increased the percentage of $\mathrm{G} 2 / \mathrm{M}$ phase cell populations from $2.6 \pm 0.2$ in the untreated cells to $8.6 \pm 0.95$ in the treated cells after the 6 -h treatment. The sub G1 peak, indicating the proportion of apoptosis, increased significantly after curcuminoids treatment for 12 and $24 \mathrm{~h}$ (data not shown). These findings suggest that curcuminoids inhibited the proliferation of HNO97 cells by promoting their cell cycle arrest in the $\mathrm{G} 2 / \mathrm{M}$ phase.

\subsection{Curcuminoids caused DNA damage in HNO97 cells}

To confirm that curcuminoids reduced HNO97 cell viability through DNA damage induction, the COMET assay was used to assess the effect of curcuminoids on DNA damage in HNO97 cells. Compared to untreated cultures, clear comet tails were observed in cells treated with curcuminoids ( $35 \mu \mathrm{M})$, and this effect was already detected at $6 \mathrm{~h}$ (Figure 5A). The incubation of HNO97 cells with curcuminoids for 24 and 48 h resulted in more DNA migration smear (comet tail) (Figure 5B) indicating that DNA damage is time-dependent in response to curcuminoids.

\subsection{Curcuminoids suppressed the colony-forming ability of $\mathrm{HNO97}$}

To test the long-term growth inhibition of curcuminoids against HNO97 cells, the colony forming ability of HNO97 cells was examined. Exposure of HNO97 cells to $35 \mu \mathrm{M}$
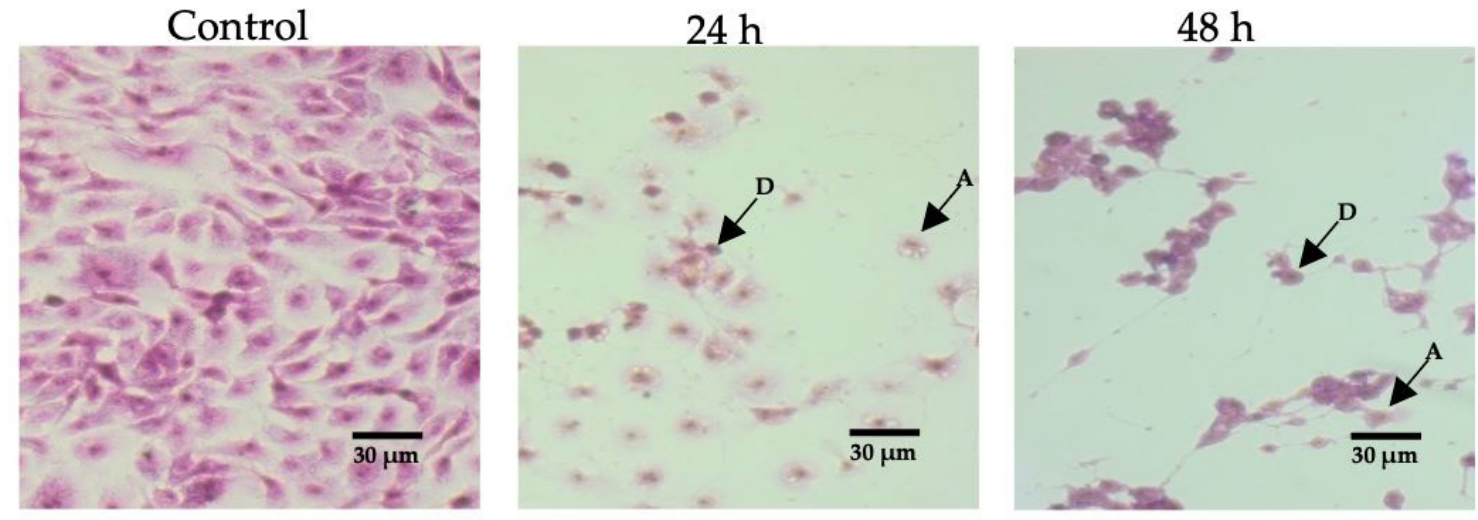

Figure 2. Morphological changes of HNO97 cells in response to curcuminoids. HNO97 cells were treated with curcuminoids for 24 and 48 h. HNO97 cells were stained with Giemsa stain and captured using a phasecontrast microscope (20x), A: Apoptotic cell, D: Detached cell. 

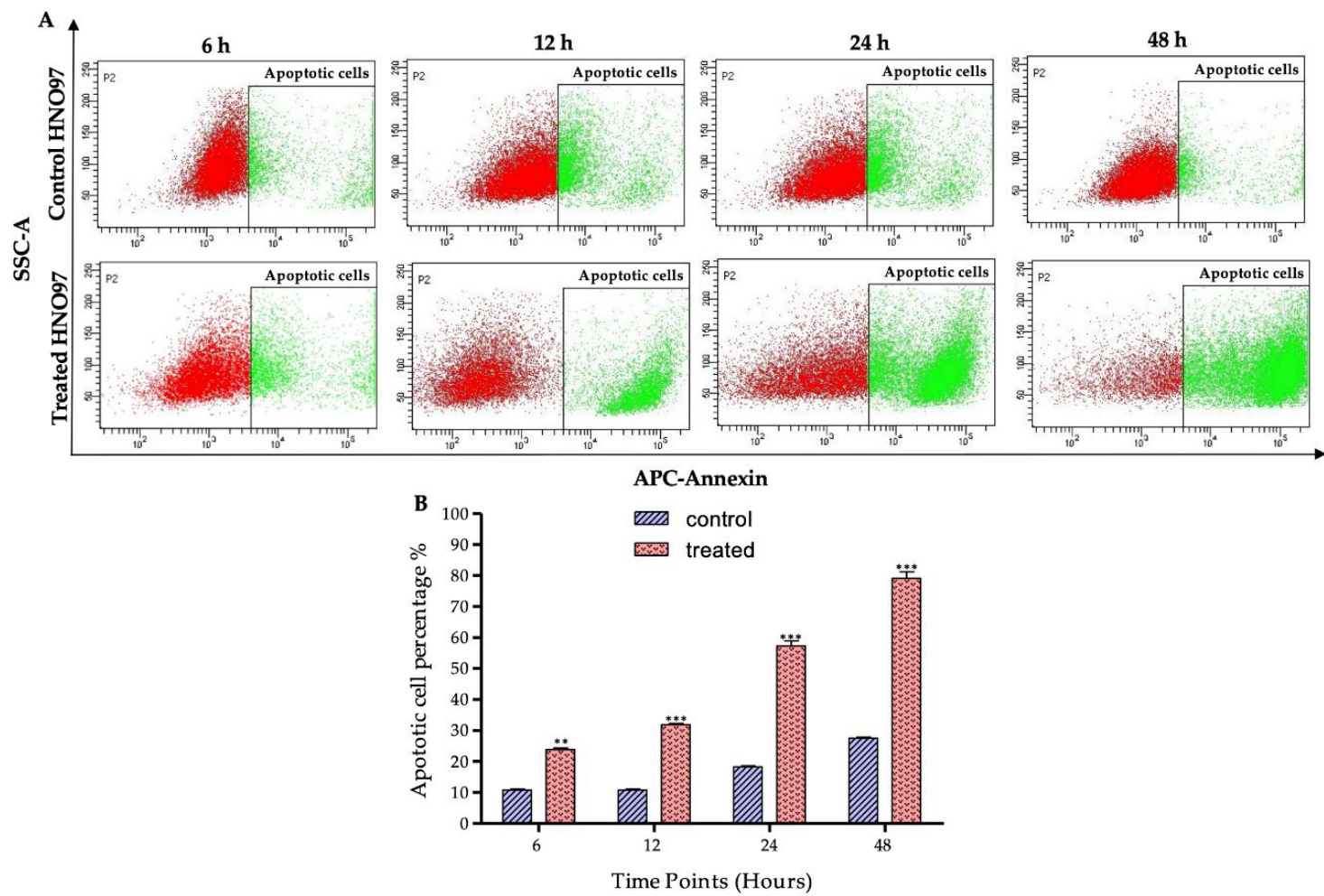

Figure 3. Apoptosis induction by curcuminoids in HNO97 cells. (A) Cells were treated with $35 \mu \mathrm{M}$ of curcuminoids for different time periods, apoptosis was then assessed by flow cytometry using APC-Annexin (green cells); (B) The number of apoptotic cells is expressed as percent relative to the total cell number. ${ }^{* *} \mathrm{p}<0.01$ and ${ }^{* * *} \mathrm{p}<0.001$ considered statistical significance compared to the untreated cells.

A

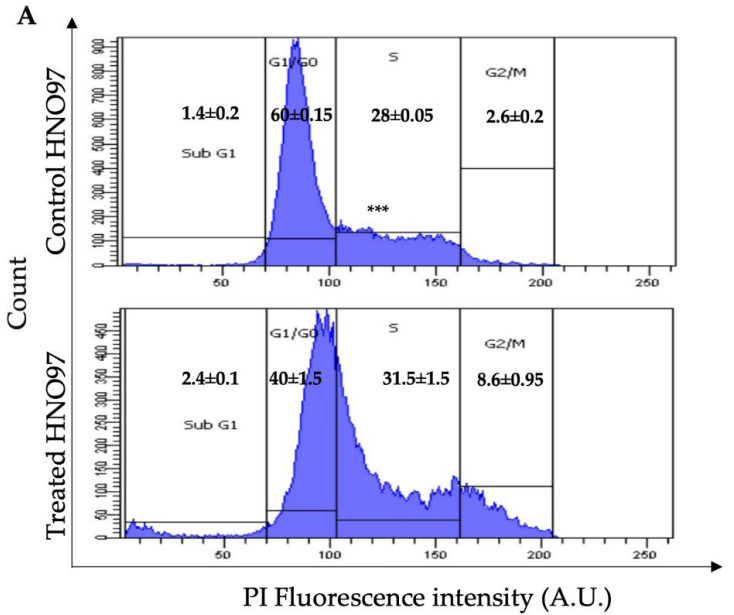

B

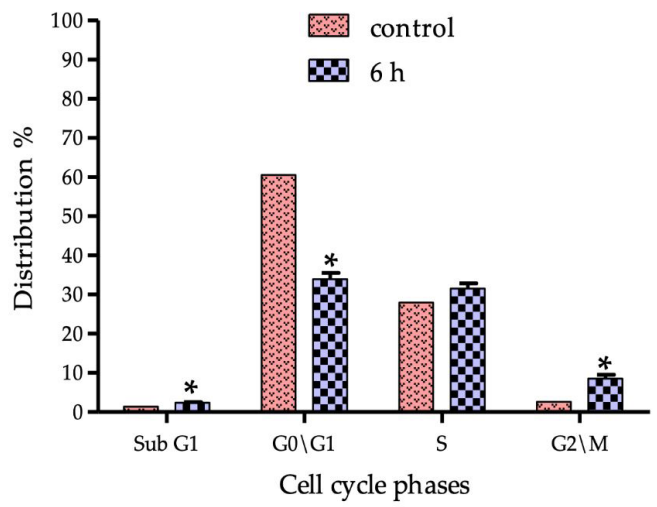

Figure 4. The cell cycle distribution of untreated and curcuminoid-treated ( $35 \mu \mathrm{M})$ HNO97 cells. (A) Flow cytometry analysis of the cell population of HNO97 cells either untreated or treated with $35 \mu \mathrm{M}$ curcuminoids for $6 \mathrm{~h}$; (B) The percentage of cell cycle phase in response to curcuminoids $(35 \mu \mathrm{M})$ at $6 \mathrm{~h}$. Values are means \pm SEM. ${ }^{*} \mathrm{p}<0.05$ considered statistical significance compared to the untreated cells.

of curcuminoids induced a significant inhibition of colony-forming ability in comparison to untreated cells. As shown in Figure 6, the number of colonies gradually reduced with the increasing exposure time of curcuminoids to HNO97 cells, indicating that curcuminoids inhibited the colony-forming ability of HNO97 cells in a timedependent manner.

\section{Discussion}

Natural agents have attracted the attention of research scientists for the development of anticancer drugs due to their therapeutic potential and a minimal side effect. In this context, curcuminoids have been shown to exert multiple anticancer activities including the inhibition of cell 

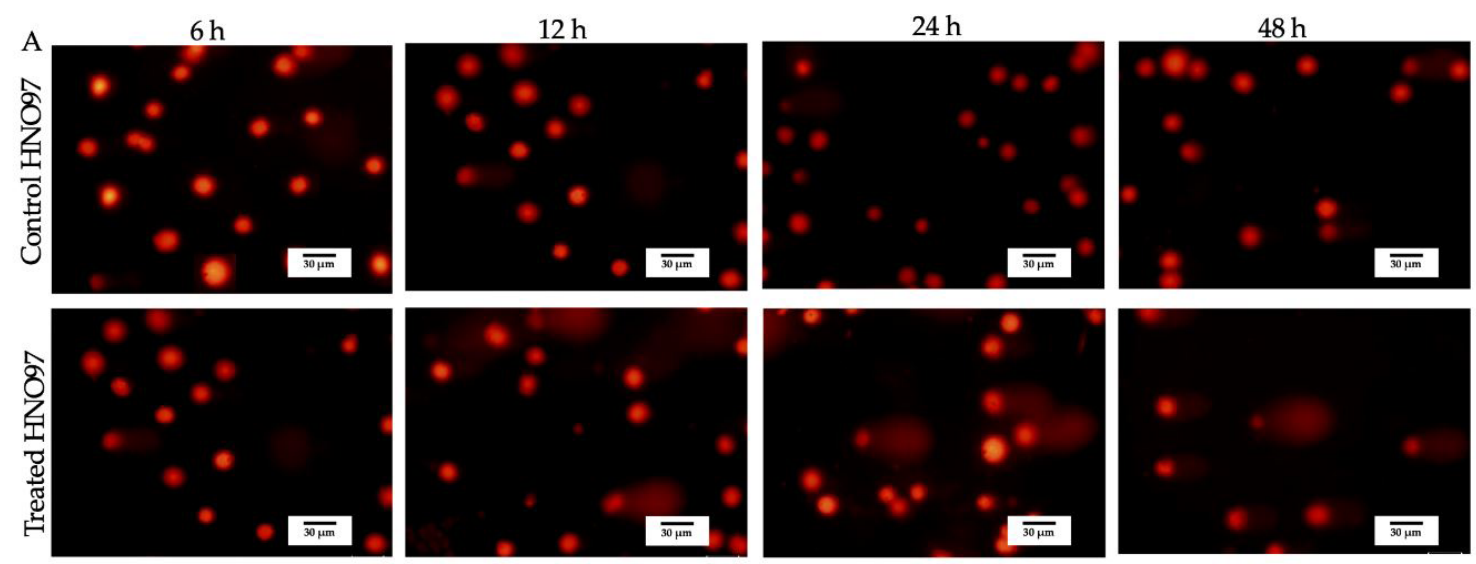

B

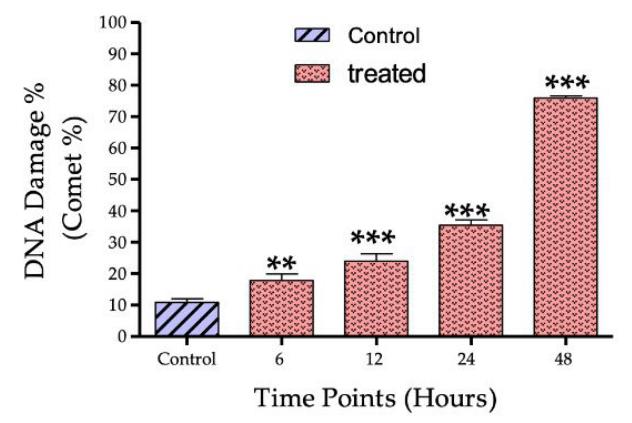

Figure 5. Curcuminoids-induced DNA damage in HNO97 cells. (A): HNO97 cells were treated with $35 \mu \mathrm{M}$ of curcuminoids for 6, 12, 24, and $48 \mathrm{~h}$, and the DNA damage level was evaluated using COMET assay. The representative image of DNA comet in HNO97 cells from each treatment was captured using a fluorescent microscope at (40x); (B): Quantification of the comet number. Values are means \pm SEM. ${ }^{* *} \mathrm{p}<0.01$ and ${ }^{* * *} \mathrm{p}<0.001$ considered statistical significance compared to the untreated cells.

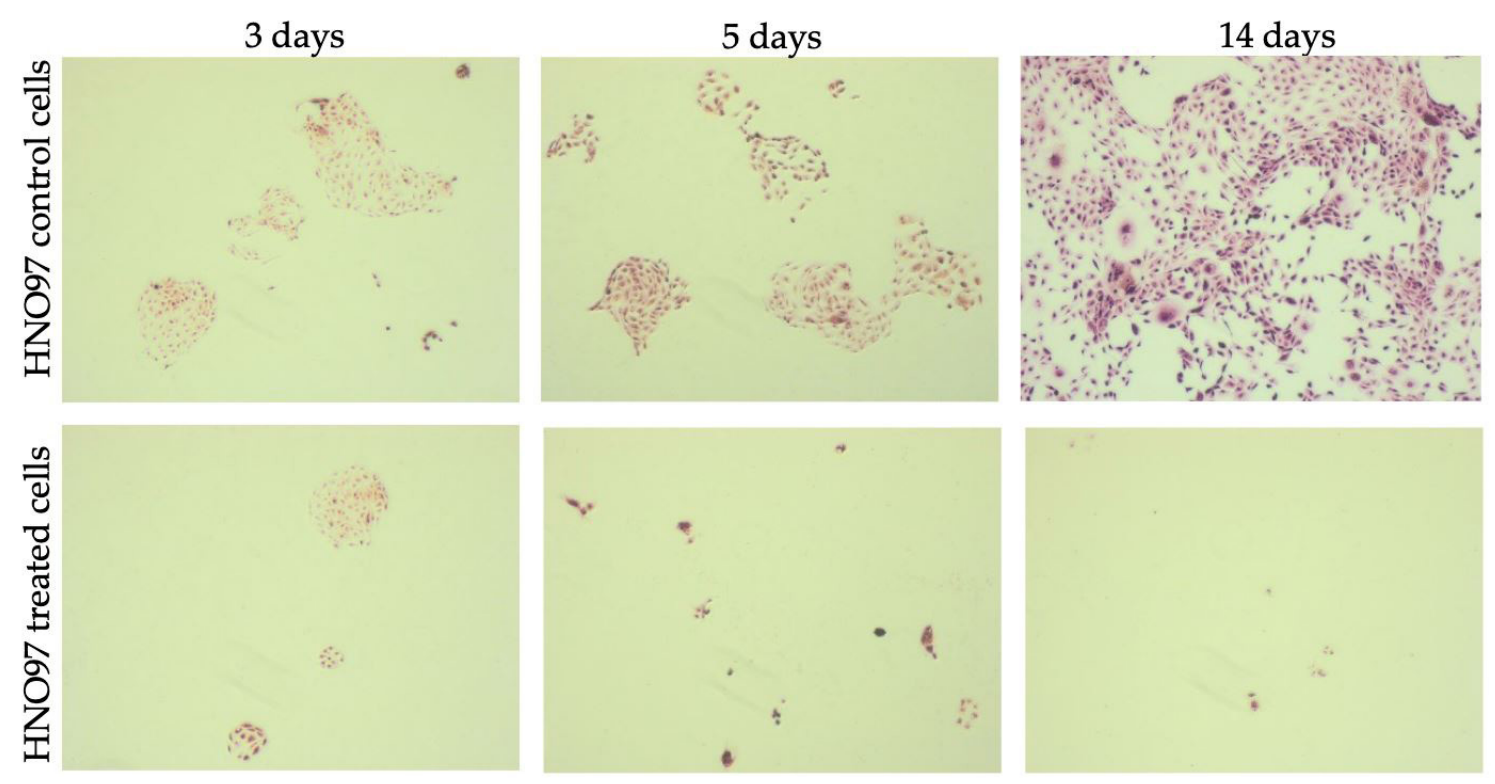

Figure 6. Effect of curcuminoids on colony formation of HNO97. Exposure of HNO97 cells to $35 \mu \mathrm{M}$ of curcuminoids for 3, 5, and 14 days were associated with significant repression of colony-forming ability. The colonies were examined under a phase-contrast microscope (4x). 
proliferation, metastasis and angiogenesis (Shakeri et al., 2019). In our previous work, we have demonstrated that curcuminoids mixture contain three main compounds: Curcumin, DMC, and BDMC (Almosa et al., 2020). Indeed, curcuminoids mixture analysis has shown three individual peaks of curcuminoids: Curcumin (81.82\%), DMC (15.09\%), and BDMC (3.10\%) indicating that curcumin is the main constituent in the mixture (Almosa et al., 2020). In the present study, we focused on studying the effect of curcuminoids mixture on cell proliferation, apoptosis, cell cycle and DNA damage of HNO97 cell line as a model of HNC. The pro-apoptotic property of curcuminoids was investigated through morphological changes of HNO97 cells. Curcuminoids-treated cells exhibited significant morphological changes including cell shrinking, cell detachment, and membrane damage. Our observations are in agreement with Shang et al. (2016), who reported that curcumin caused significant morphological changes in human cervical cancer HeLa cell (Shang et al., 2016).

Apoptosis is a tightly regulated process for initiating cell death. The normal cell function and tissue homeostasis are mentioned by an equilibrium between cellular proliferation and cellular apoptosis (Jan and Chaudhry, 2019). Cancer arises when cell proliferation and apoptosis are unbalanced and cells undergo uncontrolled proliferation and defective apoptosis (Wang et al., 2015). HNC is among the most prevalent malignant cancer where cellular proliferation and cellular apoptosis are dysregulated (Orlandi et al., 2019). One of the best approaches to treat cancer is using the cell's mechanism to the initiation of cell death (An et al., 2019). Curcumin has been extensively studied because of its ability to inhibit cancer growth and induce apoptosis. Recently, many studies suggested that curcumin can induce cell death of human lymphoblastoid (Méndez-García et al., 2019), neuroblastoma (Caruso Bavisotto et al., 2020), gastric cancer (Mu et al., 2019), and lung cancer (Chen et al., 2019). BDMC has also the ability to induce a cytotoxic effect on ovarian cancer SKOV-3 cells (Pei et al., 2016). Furthermore, DMC has also been shown to inhibit the proliferation of lung cancer $\mathrm{NCl}-\mathrm{H} 460$ cells (Ko et al., 2015). In the present study, the three main compounds of curcuminoids synergistically exhibited a cytotoxic effect against HNO97 cells and inhibited cell proliferation in a dose- and time-dependent manner. The $\mathrm{IC}_{50}$ for treatment with curcuminoids was obtained at $35 \mu \mathrm{M}$ for $24 \mathrm{~h}$ post-treatment. Furthermore, our study showed that curcuminoids treatment suppresses the colony-forming ability of HNO97 cells, suggesting that the effect of curcuminoids on the cancer cells is irreversible. To determine whether the inhibition of cell proliferation inhibition was accompanied with apoptosis, we examined HNO97 cells treated with curcuminoids at different time points. The obtained results provide evidence that curcuminoids induce apoptosis in HNO97. Therefore, the induction of apoptosis in HNO97 cells in response to curcuminoids treatment support its anticancer activity against HNC.

Cell cycle arrest is one of the main aspects of curcumin in cancer cells, which can alter the number of cells at different phases. The cell cycle consists of four phases: G1, S, G2, and M (Sa and Das, 2008). The G1 phase is the first growth stage of the cell cycle before the $S$ phase. Through the $S$ phase, the somatic cells' chromosome is replicated. The $\mathrm{G} 2$ phase is the final sub-phase in the cell cycle before chromosomes' mitosis in the M phase (Huang et al., 2008). During DNA damage, the cell cycle is arrested to provide time to repair damaged DNA. In the case of severe DNA damage, the apoptotic mechanism is triggered and the cells will undergo apoptosis (Salem et al., 2014).

Curcumin may exert its anti-cancer activity by inducing cell cycle arrest and leading to apoptosis (Salem et al., 2014). To determine whether curcuminoids induce cell cycle arrest of HNO97 cells, the cell cycle distributions were determined using flow cytometry after incubation with $35 \mu \mathrm{M}$ of curcuminoids for different time points. The provided results demonstrated that curcuminoids increased the percentages of G2/M phase cell populations in the treated groups after the $6 \mathrm{~h}$ treatment. These findings are in line with previous studies that reported DMC and curcumin induce $\mathrm{G} 2 / \mathrm{M}$ phase arrest in human glioma U87 MG cells (Lal et al., 2018) and oral SCC-25 cells (Zhen et al., 2014), respectively.

The present study provided further evidence that curcuminoids were able to induce DNA damage. In this regard, the COMET assay was used for the assessment of DNA damage. Data obtained from COMET assay clearly showed that curcuminoids at different time points induced DNA damage in HNO97 cells. The provided results are in agreement with those of other studies in human papillary thyroid carcinoma (Zhang et al., 2016), and human cervical cancer (Shang et al., 2016).

In conclusion, the findings in this research present curcuminoids as a promising natural anticancer agent since it greatly reduced the growth of HNO97 cells and has the potentials to prevent cancer development. Also, curcumin-induced DNA damage revealed a possible additional mechanism of cytotoxicity by curcuminoids. Nonetheless, further studies are needed to investigate the mechanisms of action of curcuminoids and the signal transduction pathways involved. Furthermore, studying expression changes of genes will provide an insight into the mechanism of action of curcuminoids in HNC cells and help us to understand how this natural agent can protect against HNC. Moreover, the safety and efficacy of curcuminoids would need to be investigated in animal models of HNC and clinical trials.

\section{Acknowledgements}

The authors would like to thank King Fahd Medical Research Center (KFMRC) and the Department of Biochemistry at King Abdulaziz University, where the experimental works took place. We are grateful to King Abdulaziz City of Science and Technology (KACST) for their financial support to this project, Grants No. (1-17-01-0090016).

\section{References}

ALMOSA, H., ALQRIQRI, M., DENETIU, I., BAGHDADI, M.A., ALKHALED, M., ALHOSIN, M., ALDAJANI, W.A., ZAMZAMI, M., UCISIK, M.H. and DAMIATI, S., 2020. Cytotoxicity of standardized curcuminoids mixture against epithelial ovarian cancer cell line SKOV-3. 
Scientia Pharmaceutica, vol. 88, no. 1, pp. 11. http://dx.doi. org/10.3390/scipharm88010011.

AN, W., LAI, H., ZHANG, Y., LIU, M., LIN, X. and CAO, S., 2019. Apoptotic pathway as the therapeutic target for anticancer traditional chinese medicines. Frontiers in Pharmacology, vol. 10, pp. 758. http://dx.doi.org/10.3389/fphar.2019.00758. PMid:31354479.

ANAND, P., THOMAS, S.G., KUNNUMAKKARA, A.B., SUNDARAM, C., HARIKUMAR, K.B., SUNG, B., THARAKAN, S.T., MISRA, K., PRIYADARSINI, I.K., RAJASEKHARAN, K.N. and AGGARWAL, B.B., 2008. Biological activities of curcumin and its analogues (Congeners) made by man and Mother Nature. Biochemical Pharmacology, vol. 76, no. 11, pp. 1590-1611. http://dx.doi. org/10.1016/j.bcp.2008.08.008. PMid:18775680.

CARUSO BAVISOTTO, C., MARINO GAMMAZZA, A., LO CASCIO, F., MOCCIARO, E., VITALE, A.M., VERGILIO, G., PACE, A., CAPPELLO, F., CAMPANELLA, C. and PALUMBO PICCIONELLO, A., 2020. Curcumin affects HSP60 folding activity and levels in neuroblastoma cells. International Journal of Molecular Sciences, vol. 21, no. 2, pp. 661. http://dx.doi.org/10.3390/ijms21020661.

CHEN, Q., MEN, Y., WANG, H., CHEN, R., HAN, X. and LIU, J., 2019. Curcumin inhibits proliferation and migration of A549 lung cancer cells through activation of ERK1/2 pathway-induced autophagy. Natural Product Communications, vol. 14, no. 6, pp. 6. http://dx.doi.org/10.1177/1934578X19848179.

CROOKER, K., ALIANI, R., ANANTH, M., ARNOLD, L., ANANT, S. and THOMAS, S.M., 2018. A review of promising natural chemopreventive agents for head and neck cancer. Cancer Prevention Research, vol. 11, no. 8, pp. 441-450. http://dx.doi. org/10.1158/1940-6207.CAPR-17-0419. PMid:29602908.

CROWLEY, L.C., CHRISTENSEN, M.E. and WATERHOUSE, N.J., 2016. Measuring survival of adherent cells with the colony-forming assay. Cold Spring Harbor Protocols, vol. 2016, no. 8, pp. 8. http:// dx.doi.org/10.1101/pdb.prot087171. PMid:27480717.

GOVIND, P., 2011. Active principles and median lethal dose of Curcuma longa Linn. Internafional Research Journal of Pharmacy, vol. 2, no. 5, pp. 239.

HUANG, M., MIAO, Z.H., ZHU, H., CAI, Y.J., LU, W. and DING, J., 2008. Chk1 and Chk2 are differentially involved in homologous recombination repair and cell cycle arrest in response to DNA double-strand breaks induced by camptothecins. Molecular Cancer Therapeutics, vol. 7, no. 6, pp. 1440-1449. http://dx.doi. org/10.1158/1535-7163.MCT-07-2116. PMid:18566216.

JAN, R. and CHAUDHRY, G.-S., 2019. Understanding apoptosis and apoptotic pathways targeted cancer therapeutics. Advanced Pharmaceutical Bulletin, vol. 9, no. 2, pp. 205-218. http://dx.doi. org/10.15171/apb.2019.024.

JOSHI, P., DUTTA, S., CHATURVEDI, P. and NAIR, S., 2014. Head and neck cancers in developing countries. Rambam Maimonides Medical Journal, vol. 5, no. 2, pp. 2. http://dx.doi.org/10.5041/ RMMJ.10143.

KO, Y.C., LIEN, J.C., LIU, H.C., HSU, S.C., JI, B.C., YANG, M.D., HSU, W.H. and CHUNG, J.G., 2015. Demethoxycurcumin induces the apoptosis of human lung cancer NCI-H460 cells through the mitochondrial-dependent pathway. Oncology Reports, vol. 33 , no. 5, pp. 2429-2437. http://dx.doi.org/10.3892/or.2015.3865. PMid:25813094.

LAL, N., NEMAYSH, V. and LUTHRA, P.M., 2018. Proteasome mediated degradation of CDC25C and Cyclin B1 in Demethoxycurcumin treated human glioma U87 MG cells to trigger G2/M cell cycle arrest. Toxicology and Applied Pharmacology, vol. 356, pp. 76-89. http://dx.doi.org/10.1016/j.taap.2018.07.012. PMid:30009775.

LIN, C.C., KUO, C.L., HUANG, Y.P., CHEN, C.Y., HSU, M.J., CHU, Y.L., CHUEH, F.S. and CHUNG, J.G., 2018. demethoxycurcumin suppresses migration and invasion of human cervical cancer HeLa cells via inhibition of NF-kB pathways. Anticancer Research, vol. 38, no. 5, pp. 2761-2769. PMid:29715097.

LIU, L.D., PANG, Y.X., ZHAO, X.R., LI, R., JIN, C.J., XUE, J., DONG, R.Y. and LIU, P.S., 2019. Curcumin induces apoptotic cell death and protective autophagy by inhibiting AKT/mTOR/p70S6K pathway in human ovarian cancer cells. Archives of Gynecology and Obstetrics, vol. 299, no. 6, pp. 1627-1639. http://dx.doi. org/10.1007/s00404-019-05058-3. PMid:31006841.

MÉNDEZ-GARCÍA, L.A., MARTÍNEZ-CASTILLO, M., VILLEGASSEPÚlVEDA, N., OROZCO, L. and CÓRDOVA, E.J., 2019. Curcumin induces p53-independent inactivation of Nrf2 during oxidative stress-induced apoptosis. Human and Experimental Toxicology, vol. 38, no. 8, pp. 951-961. http://dx.doi. org/10.1177/0960327119845035. PMid:31018701.

MISHRA, S. and PALANIVELU, K., 2008. The effect of curcumin (turmeric) on Alzheimer's disease: an overview. Annals of Indian Academy of Neurology, vol. 11, no. 1, pp. 13. http://dx.doi. org/10.4103/0972-2327.40220.

MU, J., WANG, X., DONG, L. and SUN, P., 2019. Curcumin derivative L6H4 inhibits proliferation and invasion of gastric cancer cell line BGC-823. Journal of Cellular Biochemistry, vol. 120, no. 1, pp. 1011-1017. http://dx.doi.org/10.1002/jcb.27542. PMid:30242876.

ORLANDI, E., ALFIERI, S., SIMON, C., TRAMA, A., LICITRA, L., HACKL, M., EYCKEN, E.V., HENAU, K., DIMITROVA, N., SEKERIJA, M., DUŠEK, L., MÄGI, M., MALILA, N., LEINONEN, M., VELTEN, M., TROUSSARD, X., BOUVIER, V., GUIZARD, A.-V., BOUVIER, A.-M., ARVEUX, P., MAYNADIÉ, M., WORONOFF, A.-S., ROBASZKIEWIC, M., BALDI, I., MONNEREAU, A., TRETARRE, B., COLONNA, M., MOLINIÉ, F., BARA, S., SCHVARTZ, C., LAPÔTRE-LEDOUX, B., GROSCLAUDE, P., STABENOW, R., LUTTMANN, S., NENNECKE, A., ENGEL, J., SCHUBERT-FRITSCHLE, G., HEIDRICH, J., HOLLECZEK, B., JÓNASSON, J.G., CLOUGH-GORR, K., COMBER, H., MAZZOLENI, G., GIACOMIN, A., SUTERA SARDO, A., BARCHIELLI, A., SERRAINO, D., DE ANGELIS, R., MALLONE, S., TAVILLA, A., PIERANNUNZIO, D., ROSSI, S., SANTAQUILANI, M., KNIJN, A., PANNOZZO, F., GENNARO, V., BENFATTO, L., RICCI, P., AUTELITANO, M., SPAGNOLI, G., FUSCO, M., USALA, M., VITALE, F., MICHIARA, M., TUMINO, R., MANGONE, L., FALCINI, F., FERRETTI, S., FILIBERTI, R.A., MARANI, E., IANNELLI, A., SENSI, F., PIFFER, S., GENTILINI, M., MADEDDU, A., ZIINO, A., MASPERO, S., CANDELA, P., STRACCI, F., TAGLIABUE, G., RUGGE, M., TRAMA, A., GATTA, G., BOTTA, L., CAPOCACCIA, R., PILDAVA, S., SMAILYTE, G., CALLEJA, N., JOHANNESEN, T.B., RACHTAN, J., GÓŹDŹ, S., BŁASZCZYK, J., KĘPSKA, K., DE LACERDA, G.F., BENTO, M.J., MIRANDA, A., DIBA, C.S., ALMAR, E., LARRAÑAGA, N., DE MUNAIN, A.L., TORRELLA-RAMOS, A., DÍAZ GARCÍA, J.M., MARCOS-GRAGERA, R., SANCHEZ, M.J., NAVARRO, C., SALMERON, D., MORENO-IRIBAS, C., GALCERAN, J., CARULLA, M., MOUSAVI, M., BOUCHARDY, C., ESS, S.M., BORDONI, A., KONZELMANN, I., RASHBASS, J., GAVIN, A., BREWSTER, D.H., HUWS, D.W., VISSER, O., BIELSKA-LASOTA, M., PRIMIC-ZAKELJ, M., KUNKLER, I. and BENHAMOU, E., 2019. Treatment challenges in and outside a network setting: head and neck cancers. European Journal of Surgical Oncology, vol. 45, no. 1, pp. 40-45. http://dx.doi.org/10.1016/j.ejso.2018.02.007. PMid:29478741.

PEI, H., YANG, Y., CUI, L., YANG, J., LI, X., YANG, Y. and DUAN, H., 2016. Bisdemethoxycurcumin inhibits ovarian cancer via reducing oxidative stress mediated MMPs expressions. Scientific Reports, vol. 6, no. 1, pp. 1-8. http://dx.doi.org/10.1038/srep28773.

RAHMAN, S.N.S.A., ABDUL WAHAB, N. and ABD MALEK, S.N., 2013. In vitro morphological assessment of apoptosis induced by antiproliferative constituents from the rhizomes of Curcuma zedoaria. Evidence-Based Complementary and Alternative Medicine, vol. 201, pp. 257108. 
RAMEZANI, M., HATAMIPOUR, M. and SAHEBKAR, A., 2018. Promising anti-tumor properties of bisdemethoxycurcumin: a naturally occurring curcumin analogue. Journal of Cellular Physiology, vol. 233, no. 2, pp. 880-887. http://dx.doi.org/10.1002/jcp.25795. PMid:28075008.

RAMEZANI, T., NABIUNI, M., BAHARARA, J., PARIVAR, K. and NAMVAR, F., 2019. Sensitization of resistance ovarian cancer cells to cisplatin by biogenic synthesized silver nanoparticles through p53 activation. Iranian Journal of Pharmaceutical Research, vol. 18, no. 1, pp. 222-231. PMid:31089357.

SA, G. and DAS, T., 2008. Anti cancer effects of curcumin: cycle of life and death. Cell Division, vol. 3, no. 1, pp. 14. http://dx.doi. org/10.1186/1747-1028-3-14. PMid:18834508.

SALEM, M., ROHANI, S. and GILLIES, E.R., 2014. Curcumin, a promising anti-cancer therapeutic: a review of its chemical properties, bioactivity and approaches to cancer cell delivery. RSC Advances, vol. 4, no. 21, pp. 10815-10829. http://dx.doi. org/10.1039/c3ra46396f.

SERONT, E., MACHIELS, J.-P. and SCHMITZ, S., 2019. Squamous cell carcinoma of the head and neck. In: R.A. DE MELLO, G. MOUNTZIOS and A. TAVARES, eds. International manual of oncology practice. Cham: Springer, pp. 697-720. http://dx.doi. org/10.1007/978-3-030-16245-0_31.

SHAKERI, A., WARD, N., PANAHI, Y. and SAHEBKAR, A., 2019. Anti-angiogenic activity of curcumin in cancer therapy: a narrative review. Current Vascular Pharmacology, vol. 17, no. 3, pp. 262-269. http://dx.doi.org/10.2174/1570161116666180 209113014. PMid:29424316.

SHANG, H.S., CHANG, C.H., CHOU, Y.R., YEH, M.Y., AU, M.K., LU, H.F., CHU, Y.L., CHOU, H.M., CHOU, H.C., SHIH, Y.L. and CHUNG, J.G., 2016. Curcumin causes DNA damage and affects associated protein expression in HeLa human cervical cancer cells. Oncology Reports, vol. 36, no. 4, pp. 2207-2215. http://dx.doi. org/10.3892/or.2016.5002. PMid:27499229.

SONG, X., ZHANG, M., DAI, E. and LUO, Y., 2019. Molecular targets of curcumin in breast cancer. Molecular Medicine Reports, vol. 19, no. 1, pp. 23-29. PMid:30483727.

TICE, R.R., AGURELL, E., ANDERSON, D., BURLINSON, B., HARTMANN, A., KOBAYASHI, H., MIYAMAE, Y., ROJAS, E., RYU, J.C. and SASAKI, Y.F., 2000. Single cell gel/comet assay: guidelines for in vitro and in vivo genetic toxicology testing. Environmental and Molecular Mutagenesis, vol. 35, no. 3, pp. 206-221. http://
dx.doi.org/10.1002/(SICI)1098-2280(2000)35:3<206::AIDEM8>3.0.CO;2-J. PMid:10737956.

VAN HARTEN, A.M., DE BOER, D.V., MARTENS-DE KEMP, S.R., BUIJZE, M., GANZEVLES, S.H., HUNTER, K.D., LEEMANS, C.R., VAN BEUSECHEM, V.W., WOLTHUIS, R.M.F., DE MENEZES, R.X. and BRAKENHOFF, R.H., 2020. Chemopreventive targeted treatment of head and neck precancer by Wee1 inhibition. Scientific Reports, vol. 10, no. 1, pp. 1-12. http://dx.doi.org/10.1038/ s41598-020-58509-2.

WANG, M., JIANG, S., ZHOU, L., YU, F., DING, H., LI, P., ZHOU, M. and WANG, K., 2019. Potential mechanisms of action of curcumin for cancer prevention: focus on cellular signaling pathways and miRNAs. International Journal of Biological Sciences, vol. 15, no. 6, pp. 1200-1214. http://dx.doi.org/10.7150/ijbs.33710.

WANG, Y.H., ZHOU, Z.B., GUO, C.A., ZHAI, J., QI, F.M. and LI, H.L., 2015. Role of mimic of manganese superoxide dismutase in proliferation and apoptosis of gastric carcinoma BGC-823 cells in vitro and in vivo. International Immunopharmacology, vol. 26, no. 2, pp. 277-285. http://dx.doi.org/10.1016/j.intimp.2015.04.003. PMid:25889634.

XU, X.-Y., MENG, X., LI, S., GAN, R.-Y., LI, Y. and LI, H.-B., 2018. Bioactivity, health benefits, and related molecular mechanisms of curcumin: current progress, challenges, and perspectives. Nutrients, vol. 10, no. 10, pp. 1553. http://dx.doi.org/10.3390/ nu10101553.

ZHANG, L., CHENG, X., GAO, Y., BAO, J., GUAN, H., LU, R., YU, H., XU, Q. and SUN, Y., 2016. Induction of ROS-independent DNA damage by curcumin leads to G2/M cell cycle arrest and apoptosis in human papillary thyroid carcinoma BCPAP cells. Food $\mathcal{E}$ Function, vol. 7, no. 1, pp. 315-325. http://dx.doi.org/10.1039/ C5F000681C. PMid:26442630.

ZHEN, L., FAN, D., YI, X., CAO, X., CHEN, D. and WANG, L., 2014. Curcumin inhibits oral squamous cell carcinoma proliferation and invasion via EGFR signaling pathways. International Journal of Clinical and Experimental Pathology, vol. 7, no. 10, pp. 64386446. PMid:25400722.

ZHU, M., ZHENG, Z., HUANG, J., MA, X., HUANG, C., WU, R., LI, X., LIANG, Z., DENG, F., WU, J., GENG, S., XIE, C. and ZHONG, C., 2019. Modulation of miR-34a in curcumin-induced antiproliferation of prostate cancer cells. Journal of Cellular Biochemistry, vol. 120, no. 9, pp. 15616-15624. http://dx.doi.org/10.1002/jcb.28828. PMid:31042325. 